\title{
Theological librarians and the Internet. Implications for practice
}

(A monograph published simultaneously as the Journal of Religious \& Theological Information, Vol.3 Nos.3/4)

Edited By Mark Stover

Binghamton: The Haworth Information Press, 2001, 219p.

ISBN 07890 । 34 I X (hbk); 07890 I342 8 (pbk)

Cost: US\$59.95 (hbk), US\$24.95 (pbk)

The Editor and the contributors to this enlightening collection of essays on the Internet and Theological librarians must be warmly congratulated on a job well done. This review is offered from the perspective of a Professor in the Faculty of Theology and Religion Studies - not a librarian or the son of a librarian!

The thirteen essays cover a multitude of aspects which every modern librarian and theological lecturer need to be aware of in order to utilise the Internet as a modern means of finding resources, publishing academic articles and communicating with students and peers.

The reader is made aware of the dictum's relevancy in Mark Stover's tone-setting essay: Internet shock: Change, continuity, and the theological librarian, (pp.l-12), that the more things change, the more they remain the same. This is especially true when it is applied to 'the timeless principles and values of librarianship'. Teachers of theology can say "amen" to the dictum. The content of theology also needs to be taught as timeless principles while recognising the values of practising theology.

Faculty members of Theological institutions are always in search of the best academic data in the minimum amount of time. Another common trait among teachers of theology is the high cost of journal subscriptions. Mark Dubis (Chapter I. Religious and theological journals online: The ATLA Serials Collection Project) has provided good news to the theological fraternity with the news that the American Theological Library Association (ATLA) created on January I, 1999, the Center for Electronic Resources in Theology and Religion (CERTR). Thus periodical literature in religion and theology can be accessed, quickly and conveniently, 'and at a reasonable cost'.

Surfing websites for specific information can easily waste precious time. A user-friendly body of catalogues made available on the Internet will prove to be a boon in the preparation of lectures and the writing of articles for publication. This will in turn engender further access to information, encourage and enable research, acquire and preserve collections and deliver resources to web clientele according to John Dickason (Chapter 2. The function of web catalogs in theological libraries), who also provided extremely useful websites in his copious notes.

Marshall Eidson's article on Electronic Journals in Religious Studies... (Chapter 3) highlights some reasons for the relatively low volume of scholarly religious studies journals on the Internet. Of special interest was his discussion on the work of the Association of Peer-Reviewed Electronic Journals in Religion. This may well provide a healthy injection of academic credibility and greater acceptance of web published material in Religious studies. Of paramount usefulness are his appendices of journals participating in the ATLA CERTR and Institutions involved as ATLA member libraries working towards filming journals for the ATLAS project. His selected yet extensive 'Webliography' of religious studies journals is worth the cost of this book under review.

The extensive and growing Accredited Theological Schools membership and its theological electronic resources needs are topics dealt with by Dave Harmeyer (Chapter 4). One of the major problems faced by distance students is the availability of resource material via the traditional and electronic means. The author lists some useful free databases. He also provides an update on the progress of the Atlas full text project under the auspices of ATLA. A comprehensive update of fee-orientated databases is provided and useful comments are provided on each.

Charles K Bellinger (Chapter 5) provides a useful "how to" article, basing his insights and advice on the available data and useful links of the Wabash Center Internet Guide.

Other applicatory friendly articles include Robert R Howard's Homiletics and Liturgics (Chapter 6) on the Internet with a most useful number of websites on the two disciplines. He warns though that discernment is necessary as '...scholarly efforts in these fields are random, with little interaction'.

Other fascinating 'how to' articles include Elizabeth Davis Deahl's Accessing Digital Images: Sources for Christian Art on the Internet (Chapter 7) and Andrew J Keck's Opening the Front Door: Designing a Usable Library Web Site (Chapter 8).

Theological teachers will find Rebecca Moore's Using the Web in Religious Studies Courses (Chapter 9) an answer to their prayers for a personal testimony of using Web-based resources in a teaching situation.

Novice researchers of Christian history will find Michael Strickland's selection of Internet Resources (Chapter 10) helpful in their exploration on the Internet

The penultimate chapter also belongs to Mark Stover. Theoretical and Conceptual Foundations for Web Site Design in Religious and Theological Academic Libraries (Chapter II), provides closely reasoned motivations for religious and theological academic libraries. Many of the principles enunciated will also apply to other academic institutions. The article provides an authoritative 'hands on' guide to the basic content of a good website in non-technical English. 
Of interest to 'novice-to-intermediate Web users' interested in Jewish issues is the final chapter on Virtually Jewish: the Creation of a Jewish Internet Tutorial by Terren Ilana Wein and Juna Z Snow. This is a dual purpose website: to help teach a Jewish audience on a 'how to' use the Web, and a 'web-based' audience who wish to obtain information about matters Jewish on the Web.

Conclusion

A most useful book for the teacher of theology, especially if web-based resources are important to the teacher and the students. This volume contains background information to the current development of web-based academic resources, and chapters on how to use the Internet in furthering religious and theological education. To this reviewer, the most valuable information is found in the many excellent listings of websites and the names of the North American institutions participating in various web related theological and religious education.

Reviewed by: Professor Arthur Song, Dean, Faculty of Theology and Religion Studies, University of Zululand, South Africa Tel.: +27 (35) 793 39l I E-mail: asong@pan.uzulu.ac.za 